\title{
DAMPAK PENGGUNAAN MODUL PENDIDIKAN KESEHATAN TERHADAP PENINGKATAN PENGETAHUAN PETUGAS PUSKESMAS
}

\author{
Risnah $^{1}$, Muhammad Irwan ${ }^{2}$ \\ 1Fakultas Kedokteran dan Ilmu Kesehatan UIN Alauddin Makassar \\ ${ }^{2}$ Fakultas Ilmu Kesehatan Universitas Sulawesi Barat \\ 1Jalan Sultan Alauddin No. 36 Samata Kab. Gowa, Sulawesi Selatan \\ 2Jalan Prof. Dr. Baharuddin Lopa, Kab. Majene, Sulawesi Barat \\ Email: risnah@uin-alauddin.ac.id ${ }^{1}$, muh.irwan@gmail.com²
}

\begin{abstract}
Abstrak:
Penelitian ini bertujuan untuk mengetahui dampak penggunaan modul pendidikan kesehatan terhadap peningkatan pengetahuan petugas puskesmas. Penelitian yang digunakan adalah kualitatif dengan pendekatan deskriptif. Populasi dalam penelitian ini adalah petugas puskesmas Binamu Kota. Subjek dalam penelitian ini merupakan keseluruhan populasi (sampel jenuh). Proses pengumpulan data dalam penelitian ini adalah observasi, studi pustaka, dan angket. Teknik analisis data menggunakan analisis deskriptif. Hasil penelitian ini menyimpulkan bahwa pengetahuan petugas puskesmas tentang gizi sebelum menggunakan modul pendidikan kesehatan dalam pelatihan memiliki rerata 3,50 dan setelah pelatihan memiliki rerata 4,67 . Hal ini berarti bahwa ada perbedaan rerata pengetahuan tentang gizi sebelum dengan setelah intervensi. Adapun kolaborasi sebelum pelatihan memiliki rerata 8,75 dan setelah pelatihan memiliki rerata 10,67. Oleh karena itu, dapat disimpulkan bahwa penggunan modul dalam kegiatan pendidikan kesehatan berdampak baik terhadap peningkatan pengetahuan petugas puskesmas Binamu Kota.
\end{abstract}

\begin{abstract}
:
The research objective was to determine the effect of the use of Health educational modules toward the knowledge improvement of health clinic staffs. The method used was qualitative method with descriptive approach. The population of this research was the staffs of Binamu Kota health clinic center. The subject was the whole staffs (saturated sample). Data collecting procedures through observation, literature study, and questionnaire. The data was analyzed in descriptively. The findings showed that the mean score of staffs' knowledge before using Health educational modules in training was 3.50 then increased to 4.67 after using it. It indicated that there were difference of the staffs' knowledge before and after using modules. While the collaboration mean score before training was 8.75 the improved to 10.67 after training. Therefore, the use of modules in health educational training influenced the staffs' knowledge of Binamu Kota health clinic center.
\end{abstract}

Kata kunci:

Modul Pendidikan Kesehatan, Pengetahuan, Puskesmas

How to Cite: Risnah, \& Irwan, M. (2019). Dampak Penggunaan Modul Pendidikan Kesehatan terhadap Peningkatan Pengetahuan Petugas Puskesmas. Lentera Pendidikan : Jurnal Ilmu Tarbiyah dan Keguruan, 22(2), 284-291. 


\section{PENDAHULUAN}

Kesehatan masyarakat yang optimal merupakan salah satu kunci penting terhadap kesuksesan sebuah negara. Kolaborasi antar profesi kesehatan menjadi suatu usaha untuk meningkatkan mutu pelayanan kesehatan yang ada. Penyelesaian permasalahan kesehatan di masyarakat sebaiknya digunakan upaya preventif dan promotif dengan tidak diabaikannya upaya kuratif dan rehabilitatif. Gerakan besar ini tentu harus didukung berbagai sektor, serta berbagai profesi. Tidak hanya profesi kesehatan, namun juga para pendidik, akademisi, bahkan para pengusaha serta profesi lainnya (Sumarni, 2015).

Dalam bidang kesehatan, salah satu konsep yang dapat diaplikasikan adalah pendidikan kesehatan. Proses pertumbuhan, perkembangan atau sebuah perubahan menjadi lebih baik, dewasa dan lebih matang pada diri individu, kelompok maupun masyarakat dapat diartikan sebagai konsep dasar dari proses belajar atau pendidikan. Proses belajar pada individu, kelompok atau masyarakat dari yang tidak mengetahui nilai-nilai kesehatan menjadi lebih tahu, dari yang tidak mampu menjadi mampu mengatasi masalah kesehatan merupakan proses pendidikan kesehatan (Suliha, 2002).

Pendidikan kesehatan memiliki manfaat jangka panjang yang dapat dilihat dalam kurung waktu beberapa tahun kemudian, sedangkan manfaat jangka pendek berupa perubahan atau peningkatan dari segi pengetahuan masyarakat. Programprogram kesehatan yang lain dapat ditunjang dengan melakukan pendidikan kesehatan. Hasil jangka menengah (intermediate impact) dari pendidikan kesehatan dengan adanya pengetahuan kesehatan berpengaruh pada perilaku dan peningkatan indikator kesehatan masyarakat sebagai keluaran (outcome) pendidikan kesehatan. Pengetahuan sikap dan kebiasaan klien yang dapat dipengaruhi oleh pengalaman belajar, baik di kelas maupun di mana saja dan kapan saja dapat dikatakan sebagai pendidikan kesehatan. Sebuah program pelatihan yang bersifat multidisiplin partisipatif inovatif untuk menerapkan pembelajaran di dunia yang sesungguhnya (Bell \& Marais, 2015). Selain itu, buku-buku pegangan telah memainkan peranan penting dalam mengurangi permasalahan kesehataan (Mudany, Sirengo, Rutherford, Mwangi, Nganga, \& Gichangi, 2015).

Pendidikan kesehatan memiliki manfaat jangka panjang (behavioral investment) yang manfaatnya baru dapat dilihat dalam kurung waktu beberapa tahun kemudian, sedangkan manfaat jangka pendek atau (immediate impact) berupa perubahan dari segi pengetahuan masyarakat. Program-program kesehatan yang lain dapat ditunjang dengan melakukan pendidikan kesehatan. Perilaku hidup sehat sebagai hasil jangka menengah (intermediate impact) dipengaruhi oleh pengetahuan mengenai kesehatan dari pendidikan kesehatan yang diberikan.

Pengetahuan merupakan hasil dari belajar dengan menggunakan penginderaan pada suatu objek. Panca indra manusia merupakan media yang baik dalam mendapatkan pengetahuan. Akan tetapi, secara umum manusia mendapatkan suatu pengetahuan melalui indra penglihatan dengan membaca dan pendengaran (Notoatmodjo, 2007b). Alat bantu dalam belajar dapat digunakan dengan berdasar 
pada prinsip bahwa panca indra yang dimiliki setiap insani akan menerima dan menangkap pengetahuan yang didapatkan. Semakin banyak menggunakan panca indra dalam menerima suatu informasi, maka semakin banyak juga pemahaman atau peningkatan pengetahuan yang didapatkan seseorang (Notoatmodjo, 2007a). Dengan demikian, penggunaan alat bantu belajar ditujukan mengerahkan indra sebanyak mungkin terhadap suatu objek hingga memberikan kemudahan dalam memahami informasi.

Sebagai upaya untuk meningkatkan pengetahuan petugas puskesmas, maka digunakan modul dalam sebuah pendidikan kesehatan. Modul dianggap sebagai salah satu cara yang dapat memberikan dampak yang baik dalam penyegaran bagi tenaga kesahatan, utamanya di puskesmas, sebab dalam modul sudah tergambar teori dan SOP sehingga mudah dipahami oleh tenaga kesehatan di puskesmas. Tujuan dari tulisan ini didasarkan pada latar belakang di atas, yaitu untuk mengetahui dampak penggunaan modul pendidikan kesehatan terhadap peningkatan pengetahuan petugas puskesmas.

\section{METODE PENELITIAN}

Penelitian ini menggunakan penelitian dengan metode deskriptif kualititatif. Bogdan dan Taylor dalam Moleong (2010) menjelaskan bahwa penelitian kualitatif merupakan prosedur penelitian yang dapat menghasilkan data deskriptif dalam bentuk lisan atau tertulis dari orang-orang dan perilaku yang dapat diamati. Sugiyono (2015) menjelaskan bahwa metode deskriptif analitis merupakan metode yang bertujuan memberi gambaran terhadap suatu objek penelitian yang diteliti melalui sampel atau data yang telah terkumpul dan membuat kesimpulan yang berlaku umum. Populasi dalam penelitian ini adalah petugas puskesmas Binamu Kota, Kabupaten Jeneponto. Adapun subjek dalam penelitian ini adalah semua populasi. Oleh karena itu, sampel dalam penelitian ini merupakan sampel jenuh. Teknik pengumpulan data yang digunakan, yaitu observasi, studi pustaka, dan angket. Analisis data menggunakan analisis deskriptif.

\section{HASIL PENELITIAN DAN PEMBAHASAN}

Penelitian ini dilaksanakan selama dua hari dengan melibatkan profesi kesehatan yang bertugas di Puskesmas Binamu Kota, Kabupaten Jeneponto. Adapun karakteristik yang menjadi responden dalam penelitian, tergambar sebagai berikut: 


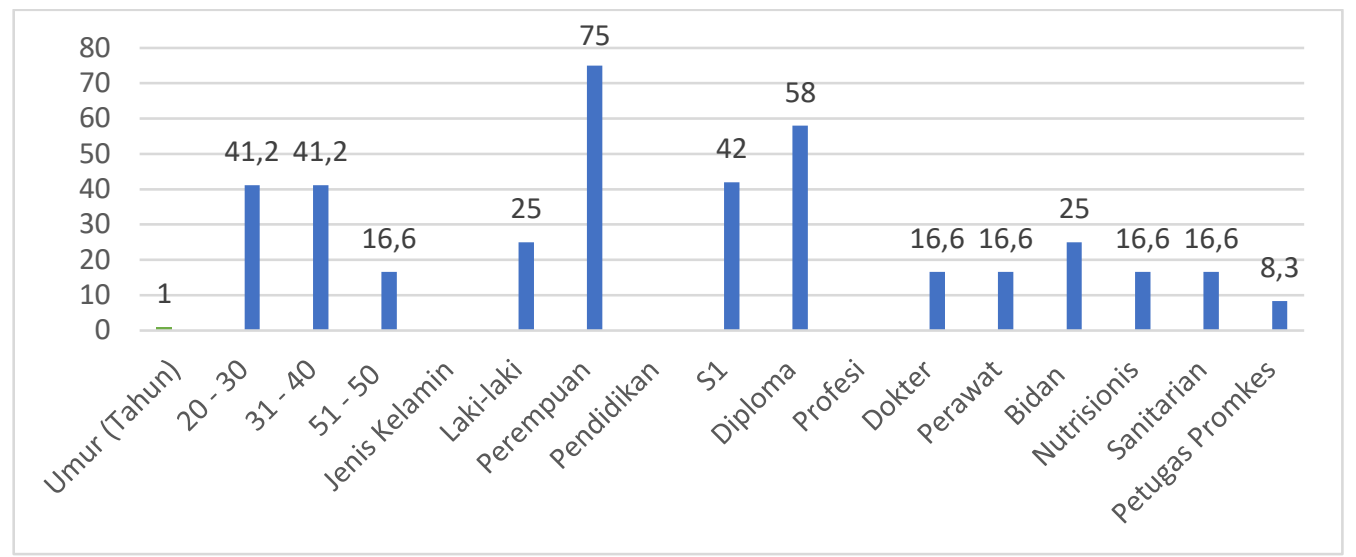

Gambar 1. Distribusi Responden Di Kab. Jeneponto Tahun 2017

Gambar 1 dalam penelitian ini dapat dilihat bahwa jenis kelamin perempuan yang menjadi mayoritas informan, yaitu berjumlah 9 orang $(75 \%)$ dan laki-laki hanya 3 orang $(25 \%)$. Berdasarkan tingkat pendidikan, informan dengan tingkat pendidikan strata 1 berjumlah 5 orang (42\%) dan informan dengan diploma III maupun diploma IV berjumlah 7 orang (58\%). Berdasarkan kelompok usia, masing-masing berjumlah 5 orang $(41,2 \%)$ informan dengan kelompok usia pada rentang usia 20 - 30 tahun dan 31 - 40 tahun dan 2 orang (16,6\%) informan dengan kelompok usia 41 - 50 tahun. Data profesi yang dimiliki informan, yakni dokter 2 orang (16,6\%), perawat 2 orang $(16,6 \%)$, bidan 3 orang (25\%), nutrionis 2 orang $(16,6 \%)$, sanitarian 2 orang $(16,6 \%)$, dan tenaga promosi kesehatan 1 orang $(8,3 \%)$. Untuk mengukur pengetahuan subjek penelitian pada penelitian ini, maka responden diberikan pretest sebelum kegiatan pelatihan dan diberikan modul saat kegiatan pelatihan berlangsung, kemudian diberikan kembali posttest setelah kegiatan pelatihan selesai dilakukan.

Tabel 1. Perubahan Pengetahuan Responden Pretest dan Posttest Pelatihan Di Kabupaten Jeneponto Tahun 2017

\begin{tabular}{lccccc}
\hline \multirow{2}{*}{ Pengetahuan } & \multicolumn{3}{c}{ Pretest } & \multicolumn{3}{c}{ Posttest } & \multirow{2}{*}{ Nilai $\boldsymbol{p}$} \\
\cline { 2 - 5 } & Mean & SD & Mean & SD & \\
\hline Gizi & 3.50 & 0.798 & 4.67 & 0.492 & 0.002 \\
\hline Kolaborasi & 8.75 & 0.965 & 10.67 & 1.670 & 0.008 \\
\hline
\end{tabular}

Tabel 1 menunjukkan adanya peningkatan rerata yang dibuktikan dengan pengetahuan mengenai gizi sebelum pelatihan diperoleh rerata 3,50 dan setelah pelatihan diperoleh rerata 4,67 . Hasil uji statistik menggunakan uji t-tes didapatkan bahwa ada perbedaan rerata pengetahuan tentang gizi sebelum dengan setelah intervensi diberikan, yang ditunjukkan dengan nilai $\mathrm{p}=0,002(\mathrm{p}<0,05)$. Adanya peningkatan rerata yang ditunjukkan dari pengetahuan tentang kolaborasi sebelum pelatihan, diperoleh rerata 8,75 dan setelah pelatihan diperoleh rerata 10,67. Adanya perbedaan rerata pengetahuan tentang kolaborasi sebelum dengan setelah intervensi 
pendidikan kesehatan diberikan yang ditunjukkan oleh hasil uji statistik dengan nilai $p=0,008(p<0,05)$. Terkait perubahan pengetahuan tersebut, nampak lebih jelas pada gambar 2 .

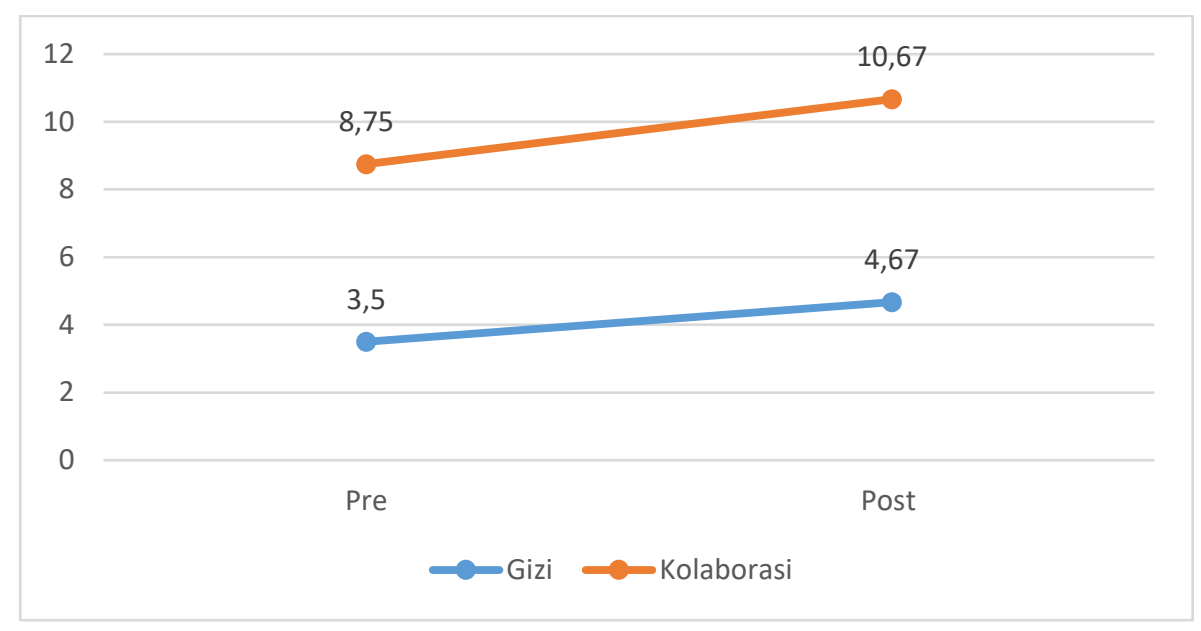

Gambar 2. Rerata Perubahan Pengetahuan Gizi dan Kolaborasi Peserta Pendidikan Kesehatan Petugas Puskesmas Di Kabupaten Jeneponto

Dalam penelitian ini, didapatkan bahwa kegiatan pelatihan yang disertai modul yang memberikan efek terhadap peningkatan pengetahuan peserta atau dapat dikatakan bahwa penggunaan modul pendidikan kesehatan memiliki dampak dalam meningkatkan pengetahuan petugas puskesmas. Hal tersebut sejalan dengan pendapat Seif \& Aziz (2002) mengatakan bahwa pengetahuan petugas puskesmas dapat berpengaruh setelah diberikan pelatihan. Salah satu contoh pelatihan yang pernah dilakukan yang dapat memberikan perubahan dalam segi pengetahuan petugasnya adalah pelatihan pemeriksaan payudara sendiri.

Meskipun telah dilakukan uji pretest dan posttest intervensi, ada juga beberapa pengetahuan yang tidak mampu diubah melalui pelatihan (Ellis \& McCreadie, Scott R. McGregory, Michael Streetman, 2007). Namun, dapat dipahami bahwa kinerja seseorang berhubungan erat dengan pengetahuan, keterampilan dan motivasi yang dimiliki (Palutturi, Nurhayani, \& Nurhamsa, 2007). Hal ini dikarenakan pelayanan kesehatan yang diberikan dihubungkan dengan faktor sosial dan psikologis seseorang (Saleh, Amir, \& Palutturi, 2012).

Upaya melakukan peningkatan pengetahuan dan kemampuan seseorang seperti diberikan informasi atau ide baru secara aktif dan diberikan dorongan atau motivasi terhadap pengarahan diri merupakan kegiatan pendidikan kesehatan yang bertujuan untuk mengingat fakta atau kenyataan di masyarakat (Suliha, 2002). Pendidikan kesehatan merupakan salah satu upaya yang dapat diaplikasikan pada bidang kesehatan. Proses pertumbuhan, perkembangan atau sebuah perubahan menjadi lebih baik, dewasa dan lebih matang pada diri individu, kelompok maupun masyarakat dapat diartikan sebagai konsep dasar dari proses belajar atau pendidikan. Proses belajar pada individu, kelompok atau masyarakat dari yang tidak mengetahui nilai- 
nilai kesehatan menjadi lebih tahu, dari yang tidak mampu menjadi mampu mengatasi masalah kesehatan merupakan proses pendidikan kesehatan. Proses peningkatan pengetahuan dan kemampuan melalui teknik praktik belajar atau pemberian instruksi, yang bertujuan untuk mengingat fakta atau kenyataan yang ada dalam kehidupan sehari-hari, dorongan terhadap pengarahan diri (self direction) yang diberikan, informasi atau ide yang baru diberikan secara aktif merupakan upaya-upaya dalam proses pendidikan kesehatan (Suliha, 2002). Suatu proses perubahan perilaku yang dinamis adalah proses dari pendidkan kesehatan.

Pada saat dilakukan kegiatan pendidikan kesehatan, maka diharapkan terjadi sebuah proses interaksi dalam upaya terjadinya transfer pengetahuan dengan harapan terjadinya perubahan perilaku dari seluruh peserta. Hal ini sesuai dengan defenisi dan tujuan dilakukannya pendidikan kesehatan. Notoatmodjo (2007a) mengungkapkan bahwa pendidikan kesehatan adalah hubungan tercapainya tujuan kesehatan pada individu, kelompok ataupun masyarakat dengan proses perubahan pada diri seseorang. Setelah dilakukan proses pembelajaran dalam interaksi kegiatan pelatihan, maka seiring dengan berjalannya waktu pengetahuan yang dibentuk dari sesuatu yang dipelajari seringkali dilupakan. Sulit mengingat pengalaman yang telah diperoleh disebabkan oleh beberapa alasan, yaitu seseorang bergantung pada apa yang diamati, pada situasi dan proses pengamatan berlangsung serta waktu yang diperlukan untuk mengamati sesuatu sehingga seseorang cenderung lupa (Purwanto, 2017). Mengutip David Kolb dalam Departemen Kesehatan (2001) bahwa sejak seseorang menerima pemaparan pengetahuan mempengaruhi hasil dari proses belajar orang tersebut. Pengetahuan dapat dipengaruhi oleh beberapa faktor, yaitu tingkat pendidikan, informasi, budaya, umur dan pengalaman serta sosial ekonomi.

Pada saat pelatihan berlangsung, maka dipergunakan modul sebagai salah satu media sarana pendukung. Kondisi ini didukung dengan teori Peluru (Bullet Theory) yang menyatakan bahwa efektifitas dari suatu pesan yang menggunakan media dapat langsung mengenai sasaran yang dituju (Liliweri, 2007), sejalan pula dengan teori yang mengungkapkan bahwa penggunaan media belajar dalam pendidikan kesehatan dengan menggunakan modul dapat memberikan kemudahan dalam penerimaan pesan-pesan kesehatan oleh masyarakat (Notoatmodjo, 2007b).

Modul yang dibaca dan dipahami dengan baik akan memberikan suatu informasi pengetahuan yang lebih banyak kepada pembacanya. Membaca berarti menangkap arti sebuah lambang atau tanda dan memberikan sebuah makna. Membaca juga merupakan usaha yang dilakukan seseorang untuk memahami suatu informasi yang mengandung arti. Membaca menuntun seseorang untuk mendapatkan informasi yang dibutuhkan dalam kehidupannya. Setiap orang memiliki perbedaan cara dalam menangkap dan menyimpan informasi apa yang telah dibaca. Perbedaan ini sangat berhubungan dengan tingkat kemahiran dalam membaca. Kemahiran membaca bisa dibagi dalam aspek mekanik atau visual dengan menggerakan kedua mata pada waktu membaca dan aspek pemahaman berhubungan dengan menangkap isi dari apa yang dibaca. Aspek mekanik berhubungan dengan indra mata seseorang, sedangkan aspek 
pemahaman berkaitan dengan otak dari pembaca. Mendengar merupakan proses awal dari penerimaan pesan yang berasal dari komunikator. Mendengarkan adalah suatu proses menangkap informasi, lalu memahami, dan mengingat sebaik-baiknya sesuatu yang telah didengarkan atau yang berkaitan dengan proses mendengarkan. Pada umumnya, setiap hari seseorang menggunakan waktu komunikasi $45 \%$ untuk sekedar mendengarkan, 30\% untuk berbicara, 16\% membaca, dan 9\% untuk menulis (Prawoto, 2009). Hal serupa juga dilakukan pada penelitian yang melaporkan bahwa terdapat perubahan terhadap pengetahuan dan perilaku ODHA setelah diberikan suatu pendidikan dan konseling gizi dengan menggunakan media pendidikan yang lebih lengkap dan dengan proses secara berkelanjutan (Hudayani \& Sartika, 2016).

Keluaran (outcome) dari pendidikan kesehatan berhubungan pada peningkatan indikator atau mutu kesehatan masyarakat. Sepanjang klien atau individu dapat mempengaruhi pengetahuan sikap dan kebiasaan yang dimiliki dari beberapa pengalaman yang diperoleh dimana dan kapan saja maka hal tersebut merupakan proses dari pendidikan kesehatan, bukan hanya diperoleh dari pelajaran di kelas (Suliha, 2002). Tidak pula terlepas dari hubungan antara pengetahuan, pelatihan dan ketersediaan sarana dalam masyarakat (Nurkhasanah \& Sujianto, 2014). Oleh karena itu, salah satu upaya yang sangat diperlukan untuk meningkatkan kualitas pelayanan kesehatan yaitu mengadakan kegiatan pelatihan dengan menggunakan modul. Hasil penelitian ini belum dapat direpresentasikan sebagai hasil pada tingkat puskesmas di Kabupaten Jeneponto secara keseluruhan karena terbatasnya jumlah responden yang belum mewakili seluruh profesi atau tenaga kesehatan yang bekerja di puskesmas tempat lokasi penelitian dilakukan.

\section{SIMPULAN}

Berdasarkan hasil penelitian dapat disimpulkan bahwa ada perbedaan rerata pengetahuan tentang gizi sebelum dengan setelah intervensi. Pengetahuan petugas puskesmas tentang gizi sebelum menggunakan modul pendidikan kesehatan dalam pelatihan memiliki rerata 3,50 dan setelah pelatihan memiliki rerata 4,67. Hal ini berarti bahwa ada perbedaan rerata pengetahuan tentang gizi sebelum dengan setelah intervensi. Adapun kolaborasi sebelum pelatihan memiliki rerata 8,75 dan setelah pelatihan memiliki rerata 10,67. Oleh karena itu, penggunan modul dalam kegiatan pendidikan kesehatan berdampak baik terhadap peningkatan pengetahuan petugas puskesmas Binamu Kota dan disarankan untuk mengadakan pendidikan kesehatan disertai modul serupa pada lokasi puskesmas yang lain untuk meningkatkan kualitas pelayanan kesehatan.

\section{DAFTAR PUSTAKA}

Bell, J. S., \& Marais, D. (2015). Participatory Training in Monitoring and Evaluation for Maternal and Newborn Health Programmes. Global Journal of Health Science, 7 (2), 192-202. https:// doi.org/10.5539/gjhs.v7n2p192 
Ellis, J. J., \& McCreadie, Scott R. McGregory, Michael Streetman, D. S. (2007). Effect of Pharmacy Practice Residency Training on Residents' Knowledge of and Interest in Clinical Research. American Journal of Health-System Pharmacy, 64 (19), 20552063. Retrieved from https://academic.oup.com/ajhp/articleabstract/64/19/2055/5134990?redirectedFrom=fulltext

Hudayani, F., \& Sartika, R. (2016). Knowledge and Behavior Change of People Living with HIV through Nutrition Education and Counseling. Kesmas: Jurnal Kesehatan Masyarakat Nasional, 10(3), 107-112.

Kesehatan, D. (2001). Modul Pelatihan Metode dan Teknologi Diklat (METEK). Jakarta: Pusat Pendidikan dan Latihan Pegawai Depkes RI.

Liliweri. (2007). Dasar-dasar Komunikasi Kesehatan. Yogyakarta: Pustaka Pelajar.

Mudany, M. A., Sirengo, M., Rutherford, G. W., Mwangi, M., Nganga, L. W., \& Gichangi, A. (2015). Enhancing Maternal and Child Health using a Combined Mother \& Child Health Booklet in Kenya. Journal of Tropical Pediatrics, 61, 442 447. https://doi.org/10.1093/tropej/fmv055

Notoatmodjo. (2007a). Kesehatan Masyarakat Ilmu dan Seni. Jakarta: PT. Rineka Cipta.

Notoatmodjo. (2007b). Promosi Kesehatan dan Ilmu Perilaku (Cet. I). Jakarta: PT. Rineka Cipta.

Nurkhasanah, \& Sujianto, U. (2014). Kepatuhan Perawat dalam Penerapan Kewaspadaan Universal di Rumah Sakit Dokter Kariadi Semarang Tahun 2013. In Prosiding Konferensi Nasional II PPNI Jawa Tengah (pp. 222-228). Retrieved from https://jurnal.unimus.ac.id/index.php/psn12012010/article /view/1146/1200

Palutturi, S., Nurhayani, \& Nurhamsa, M. (2007). Determinan Kinerja Bidan di Puskesmas Tahun 2006. Jurnal Manajemen Pelayanan Kesehatan, 10(4), 195-200.

Prawoto. (2009). Pembelajaran Mendengarkan. Jakarta: Departemen Pendidikan Nasional.

Purwanto, M. N. (2017). Psikologi Pendidikan Remaja (Cet. 28). Jakarta: Rosdakarya.

Saleh, P. A., Amir, M. Y., \& Palutturi, S. (2012). Hubungan Faktor Sosial dan Psikologis dengan Pemanfaatan Pelayanan Kesehatan di RS Bhayangkara Makassar. Jurnal Penelitian Administrasi dan Kebijakan Kesehatan FKM Universitas Hasanuddin.

Seif, N., \& Aziz, M. (2002). Effect of Breast Self-Examination Training Program on Knowledge, Attitude and Practice of a Group of Working Women. J Egypt Natl Canc Inst, 12(2), 105-115.

Suliha. (2002). Pendidikan Kesehatan dalam Keperawatan. Jakarta: Penerbit Buku Kedokteran EGC.

Sumarni, S. (2015). Peran Sarjana Kesehaatan Masyarakat dalam Gerakan Penyelamatan 1000 Hari Pertama Kehidupan untuk Menurunkan Stunting dan Angka Kematian Ibu. In Conference: Seminar Nasional dan Saresehan Kesehatan Masyarakat, At Surabaya, Indonesia. Retrieved from https://www. researchgate.net/publication/319377130_Peran_Sarjana_Kesehatan_Masyarak at_Dalam_Gerakan_Penyelamatan_1000_Hari_Pertama_Kehidupan_Untuk_M enurunkan_Stunting_Dan_Angka_Kematian_Ibu 